\title{
Exploitation of pearl millet germplasm for identification of low grain phytate containing parental lines
}

\author{
MK Berwal, P Goyal \& LK Chugh
}

Journal of Agriculture and Ecology

ISSN: 2456-9410

Volume: 6

Journal of Agriculture and Ecology (2018) 6: 39-46 http://doi.org/10.53911/JAE.2018.6205

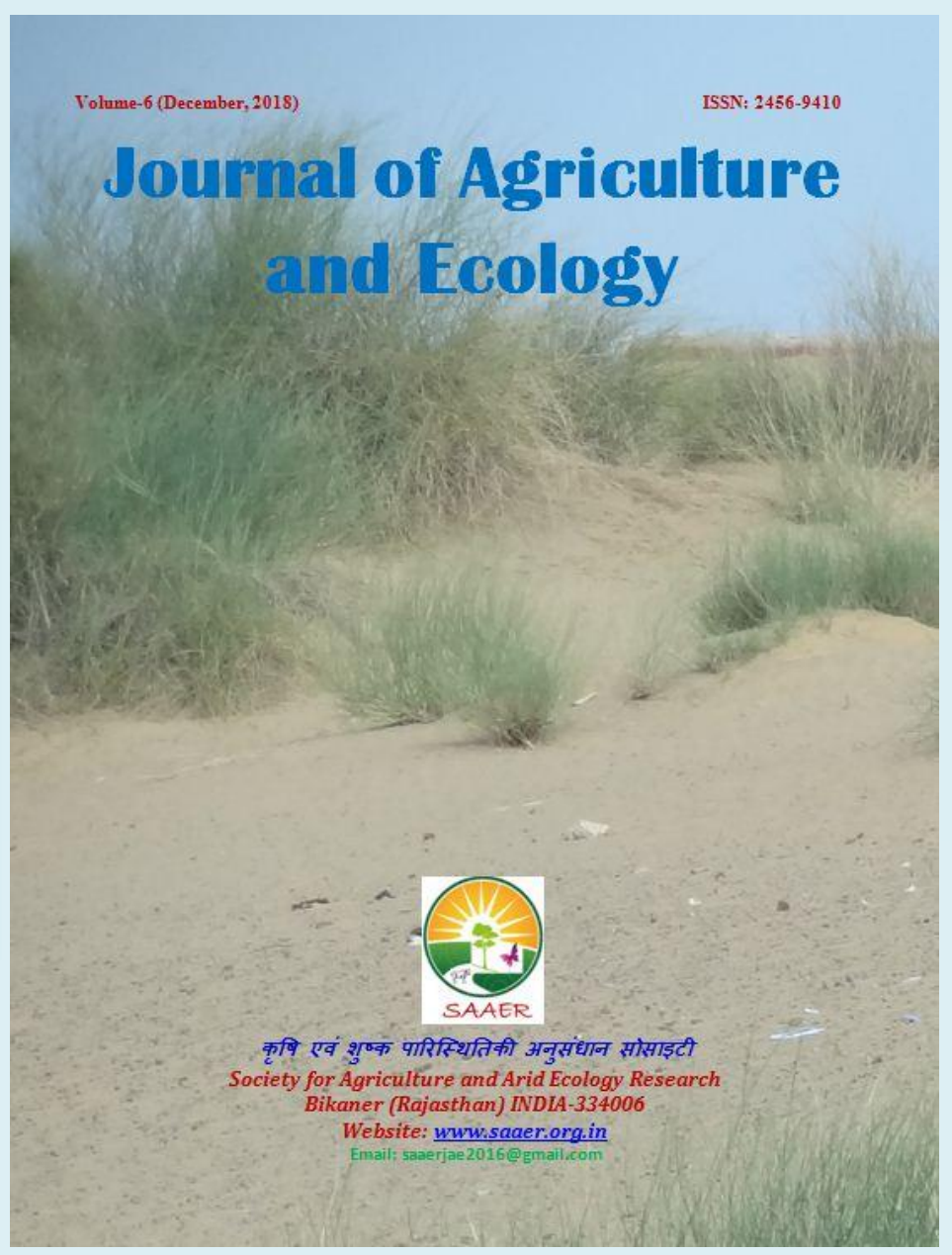




\title{
Exploitation of pearl millet germplasm for identification of low grain phytate containing parental line
}

\author{
MK Berwalম, P Goyal \& LK Chugh ${ }^{1}$ \\ Department of Chemistry and Biochemistry \\ ${ }^{1}$ Bajra Section, Department of Genetics and Plant Breeding \\ CCS Haryana Agricultural University Hisar, Haryana India-125001 \\ \Corresponding author: MK Berwal, E-mail: mkbiochem@gmail.com
}

\begin{tabular}{l}
\hline Article Info \\
\hline Article history \\
Received: 30 July 2018 \\
Accepted: 20 August 2018 \\
Available online: 25 \\
September 2018 \\
\hline
\end{tabular}

Key Words: Pearl millet, inbred lines, CMS lines, grain phytate content.

\begin{abstract}
The present study was carried out to identify low grain phytate containing pearl millet parental lines amongst advanced inbred lines and designated Bline (counterpart of CMS lines) . A total number of 92 lines (46 each of inbreds and designated $\mathrm{B}$ line) were grown in a randomized block design with two replications during kharif-2013 and 33 selected (14 inbreds and 19 designated B-lines) from kharif-2013 were grown in kharif-2014 as well. Analysis of variance indicated significant differences between the tested genotypes during both the seasons. the phytate content varied from 4.45 to $6.80 \mathrm{mg} / \mathrm{g}$ and 1.31 to $6.19 \mathrm{mg} / \mathrm{g}$ during kharif-2013 in advanced inbred lines and designated B-lines respectively. Almost similar results were observed during kharif-2014, except the like with $1.31 \mathrm{mg} / \mathrm{g}$ phytate content during kharif-2013 was not stable and in kharif -2014, the phytate content for this line was $6.87 \mathrm{mg} / \mathrm{g}$. Since none of the genotype screened showed low phytate content, therefore a large number of breeding lines are needed to be tested to know their genetic potential for low phytate.
\end{abstract}

Copyright (C2018 Berwal et al., This is an open access article published under the terms of the Creative Commons Attribution License, which permits unrestricted use, distribution, and reproduction in any medium, provided the original work is properly cited.

Preferred citation: Berwal MK, Goyal P \& Chugh LK. 2018. Exploitation of pearl millet germplasm for identification of low grain phytate containing parental line. Journal of Agriculture and Ecology, 6: 39-46; http://doi.org/10.53911/JAE.2018.6205.

\section{Introduction}

Pearl millet (Pennisetum glaucum (L.) R. Br.) is an important coarse grain cereal and forage crop in arid and semi-arid tropics of the Indian subcontinent and several African regions and is a central component of the food and fodder security of the rural poor population in these areas. The pearl millet grain is small but has a proportionally larger germ than all other cereal grains, except maize (Taylor 2004). It is a rich source of dietary fibre, essential fatty acids, protein (17\%), oil (32\%), ash (10.4\%), vitamins, and dietary 
minerals along with micronutrients like iron and zinc. Pearl millet grains also a good source of natural antioxidant compounds like phenols (Berwal et al. 2016a) and total antioxidant activity (Berwal et al. 2016b). Its contains $>1000 \mu \mathrm{g}$ vit.C equi/g total antioxidant activity (Berwal et al. 2016b). Besides its nutrional richness it also contains some antinutritional factors. Among all the anti-nutritional components, phytic acid is of prime concern for human nutrition and health management. The chemical description for phytic acid is myoinositol $(1,2,3,4,5,6)$ hexakisphosphoric acid also called as IP6. The unique structure of phytic acid offers it the ability to strongly chelate with cations such as calcium, magnesium, zinc, copper, iron and potassium to form insoluble salts and consequently, adversely affects the absorption and digestion of these minerals by human and animals (Raboy 2001). Therefore, phytic acid is considered to be an anti-nutrient that renders these minerals unavailable for absorption and also interferes with utilization of proteins (Selle et al. 2000). Along with reducing cations bio-availability, monogastric animals (human beings, dogs, pigs, birds or agastric animals) are unable to remove the phosphates from the myo-inositol ring because they lack the intestinal digestive enzyme phytase (Holm et al. 2002), and are, therefore, incapable of utilizing the phosphorus present in food grains (Kuwano et al. 2006). Therefore, to avoid above mentioned negative effects of high phytate conetent, it is necessary to develop some pearl millet varieties with low phytate content and conventional plant breeding approaches are the cheapest method for achieving this objective. For this, it is first and foremost important thing to have some low phytate containing parental lines, therefore, the present investigation was carried out to identify the low phytate containing pearl millet parental line to develop pearl millet hybrids or composites with minimum grain phytate content.

\section{Materials and Methods}

The present study was carried out to observe the variability for phytate content in advanced inbred lines and designated B-line (counterpart of CMS lines) developed at CCS HAU, Hisar and ICRISAT, Hyderabad. A total number of 92 genotypes including 46 each of inbred lines and designated $\mathrm{B}$ line were grown in randomized block design with two replications and $10 \mathrm{~cm}$ intra-row and 45 $\mathrm{cm}$ inter-row spacing at Research Farm of CCS HAU, Hisar during kharif-2013 and selected 33 lines during kharif-2014 as well. All the recommended agronomic practices were followed. The grain samples freed of extraneous matter were stored at ambient temperature for further use.

\section{Phytate Estimation}

Phytate was determined by employing the method of Haug and Lantgsch (1983). Finely ground grain sample (500 mg) was extracted with $25 \mathrm{ml}$ of $0.2 \mathrm{~N} \mathrm{HCl}$ for 3 hours with continuous shaking on orbital shaker. After proper shaking it was filtered through whatman No. 1 filter paper. The filtrate was used for Phytate estimation. An aliquot (0.5) of above sample extract was taken in a test tubes and $0.9 \mathrm{ml}$ distilled water was added. To all the tubes $1 \mathrm{ml} 0.02 \%$ ferric ammonium sulphate solution (prepared in $0.2 \mathrm{~N} \mathrm{HCl}$ ) was 
added and then placed in a boiling water bath for 30 minute. One $\mathrm{ml}$ of supernatant was transferred to another test tube and $1.5 \mathrm{ml} \mathrm{1 \%}$ bipyridine solution was added. The absorbance was measured UV-Vis spectrophotometer (Thermo Scientific, EVOLUTION 201) at $519 \mathrm{~nm}$ against distilled water blank. Phytate was calculated by using standard curve of sodium Phytate $(200 \mu \mathrm{g} / \mathrm{ml})$. Analysis of variance for randomized block design was carried out for protein content according to as described Panse \& Sukhatame (1957).

\section{Results and Discussion}

Phytate content of pearl millet inbreds (Table 1) and designated B-lines (Table 2) of grown during kharif-2013 significantly varied from 1.31 to $6.80 \mathrm{mg} / \mathrm{g}$. Average phytate content of these genotypes was $5.63 \mathrm{mg} / \mathrm{g}$. During kharif- 2014 season phytate content of these genotypes varied from 4.72 to $7.16 \mathrm{mg} / \mathrm{g}$ and an average phytate content of these was $5.99 \mathrm{mg} / \mathrm{g}$. Variation in phytate content of individual genotypes of each group grown during kharif-2013 and kharif-2014 is described below.

\section{Inbred lines}

Results on phytate content of inbred lines grown during kharif-2013 varied significantly from 4.45 to $6.80 \mathrm{mg} / \mathrm{g}$ with an average of $5.93 \mathrm{mg} / \mathrm{g}$ (Table 1). HBL 11 (4.45 $\mathrm{mg} / \mathrm{g}$ ), G 73/107 (4.48 mg/g), HBL 1120 (4.69 $\mathrm{mg} / \mathrm{g})$, HTP $94 / 54-1(4.88 \mathrm{mg} / \mathrm{g})$ and HBL 112/H12/1011 (4.95 mg/g) having less than 5 $\mathrm{mg} / \mathrm{g}$ were identified as intermediate phytate lines. Phytate content of the nine inbreds including five selected lines grown during kharif-2014 was significantly higher than that recorded during kharif-2013 for the respective lines. On the other hand, three other lines selected for other character also raised during kharif-2014 season accumulated significantly more phytate compared to preceding season (Table 2). HBL 11 (5.04 mg/g), HTP 94/54$1(5.05 \mathrm{mg} / \mathrm{g})$ and HBL 112/H12/1011 (4.84 $\mathrm{mg} / \mathrm{g}$ ) could be termed as intermediate based on average phytate content recorded in both the seasons.

Table 1. Phytate content (mg/g) of pearl millet inbreds grown during kharif-2013

\begin{tabular}{clcclcc}
\hline S. No. & Pedigree & Phytate & & S. No. & Pedigree & Phytate \\
\cline { 1 - 2 } \cline { 5 - 6 } 2 & B08/2013 & 5.94 & & 24 & HBL-0854 & 6.53 \\
2 & Brs-10-2 & 6.39 & & 25 & HBL-0902-1 & 5.07 \\
3 & Brs-10-6 & 6.38 & & 26 & HBL-0902-5 & 5.78 \\
4 & Brs-10-7 & 6.52 & & 27 & HBL-0904-1 & 5.72 \\
5 & DPHBL-11-123 & 6.71 & & 28 & HBL-0904-2 & 5.61 \\
6 & EBLT-11-101 & 5.91 & & 29 & HBL-0906-2 & 5.84 \\
7 & EBLT-11-114 & 5.52 & & 30 & HBL-0906-3 & 6.25 \\
8 & HBL- 0703 & 6.45 & & 31 & HBL-1108 & 5.41 \\
9 & HBL-0508 & 6.74 & & 32 & HBL-112/H12/1011 & 4.95 \\
10 & HBL-0510-2 & 6.13 & & 33 & HBL-1120 & 4.69 \\
11 & HBL-0547 & 5.60 & & 34 & HBL-34 & 6.05 \\
12 & HBL-0561 & 6.71 & & 35 & HBL-72 & 5.50
\end{tabular}




\begin{tabular}{|c|c|c|c|c|c|}
\hline 13 & HBL-0620 & 6.36 & 36 & HBL-828-1 & 5.88 \\
\hline 14 & HBL-0706 & 6.09 & 37 & ICMB-88006 & 5.36 \\
\hline 15 & HBL-0802 & 6.54 & 38 & LPBL-10/112 & 6.14 \\
\hline 16 & HBL-0809 & 6.00 & 39 & LPBL-10/120 & 5.72 \\
\hline 17 & HBL-0825-1 & 6.65 & 40 & TPBL-11-109 & 5.96 \\
\hline 18 & H-1305 & 6.29 & 41 & $94 / 54-1$ & 4.88 \\
\hline 19 & HBL-0828-2 & 6.62 & 42 & G-73/107 & 4.48 \\
\hline 20 & HBL-0832 & 6.80 & 43 & HTP-94/54 & 5.62 \\
\hline 21 & HBL-0843-2 & 6.51 & 44 & HBL-11 & 4.45 \\
\hline 22 & HBL-0843-4 & 6.55 & 45 & H-77/833-2-202 & 6.06 \\
\hline \multirow[t]{5}{*}{23} & HBL-0847-3 & 6.03 & 46 & $78 / 711$ & 5.42 \\
\hline & & & & Mean & 5.93 \\
\hline & C.D. $(p<0.05)$ & 0.40 & & C.D. $(p<0.05)$ & 0.40 \\
\hline & $\mathrm{SE}(\mathrm{d})$ & 0.20 & & $\mathrm{SE}(\mathrm{d})$ & 0.20 \\
\hline & C.V. $(\%)$ & 3.34 & & C.V. $(\%)$ & 3.34 \\
\hline
\end{tabular}

Table 2. Phytate content (mg/g) of selected pearl millet inbreds grown during kharif-2013 and kharif-2014

\begin{tabular}{clccc}
\hline \multirow{2}{*}{ S. No. } & Pedigree & \multicolumn{2}{c}{ Phytate } & Mean \\
\cline { 3 - 4 } & & K-13 & K-14 & 5.04 \\
2 & HBL-11 & 4.45 & 5.63 & 5.34 \\
3 & G-73/107 & 4.48 & 6.20 & 5.05 \\
4 & HB/54-1 & 4.88 & 5.22 & 4.84 \\
5 & LPBL-112/H12/1011 & 4.95 & 4.72 & 5.75 \\
6 & LPBL-10/120 & 5.72 & 5.78 & 5.75 \\
7 & H-1305 & 5.72 & 5.78 & 5.94 \\
8 & HBL-0843-4 & 6.29 & 5.58 & 6.05 \\
9 & DPHBL-11-123 & 6.55 & 5.54 & 6.53 \\
\hline & Mean & 6.71 & 6.34 & \\
& C.D. $(\mathrm{p}<0.05)$ & - & 5.64 & \\
& SE(d) & 0.40 & 0.15 & \\
& C.V. $(\%)$ & 0.20 & 0.1 & 1.25 \\
\hline
\end{tabular}

\section{Designated B-lines (CMS lines)}

Unlike inbred lines, designated B-lines showed wide variation in accumulation of phytate in grains when these lines were grown during kharif-2013. Data presented in table 3 depict that phytate content of designated Blines (CMS lines) varying from 1.31 to 6.19 $\mathrm{mg} / \mathrm{g}$ with an average deposition of $5.26 \mathrm{mg} / \mathrm{g}$, which was lower than inbred lines. HMS 13B
$(1.31 \mathrm{mg} / \mathrm{g})$, HMS 39B $(3.85 \mathrm{mg} / \mathrm{g})$, HMS 36B (3.89 mg/g), HMS 33B (4.07 mg/g), HMS 40B (4.29) and HMS 21B (4.46 mg/g) were identified as low phytate lines with less than $4.5 \mathrm{mg} / \mathrm{g}$ phytate and were selected for testing their phytate content during the coming season. During kharif-2014 all selected lines for low phytate content had high phytate 
content (Table 4). It varied from 5.53 to $7.16 \mathrm{mg} / \mathrm{g}$ with an average value of $6.25 \mathrm{mg} / \mathrm{g}$.

Table 3. Phytate content ( $\mathrm{mg} / \mathrm{g}$ ) of pearl millet designated B-lines (CMS Lines) grown during kharif-2013

\begin{tabular}{|c|c|c|c|c|c|}
\hline S. No. & Pedigree & Phytate & S. No. & Pedigree & Phytate \\
\hline 1 & HMS 7B & 4.73 & 24 & HMS 42B & 5.31 \\
\hline 2 & HMS 7B-1 & 5.82 & 25 & HMS 44B & 5.55 \\
\hline 3 & HMS 13B & 1.31 & 26 & HMS 45B & 5.16 \\
\hline 4 & HMS 14B & 5.80 & 27 & HMS 46B & 5.23 \\
\hline 5 & HMS 16B & 5.86 & 28 & HMS 49B & 6.03 \\
\hline 6 & HMS 18B & 5.98 & 29 & HMS 50B & 5.85 \\
\hline 7 & HMS 20B & 5.56 & 30 & HMS 51B & 5.66 \\
\hline 8 & HMS 21B & 4.46 & 31 & HMS 52B & 4.80 \\
\hline 9 & HMS 22B & 5.64 & 32 & HMS 53B & 5.90 \\
\hline 10 & HMS 23B & 5.27 & 33 & HMS 55B & 5.34 \\
\hline 11 & HMS 26B & 5.73 & 34 & HMS 56B & 5.75 \\
\hline 12 & HMS 28B & 5.77 & 35 & HMS 57B & 5.58 \\
\hline 13 & HMS 29B & 6.19 & 36 & HMS 58B & 5.04 \\
\hline 14 & HMS 30B & 5.34 & 37 & HMS 59B & 5.99 \\
\hline 15 & HMS 32B & 5.68 & 38 & HMS 60B & 5.14 \\
\hline 16 & HMS 33B & 4.07 & 39 & HMS 61B & 5.58 \\
\hline 17 & HMS 34B & 5.10 & 40 & HMS-18A & 4.87 \\
\hline 18 & HMS 36B & 3.89 & 41 & ICMB-89111 & 5.69 \\
\hline 19 & HMS 37B & 5.19 & 42 & ICMB-95222 & 5.68 \\
\hline 20 & HMS 38B & 5.19 & 43 & ICMB-97111 & 5.51 \\
\hline 21 & HMS 39B & 3.85 & 44 & ICMB-94555 & 4.94 \\
\hline 22 & HMS 40B & 4.29 & 45 & ICMB-94222 & 4.95 \\
\hline \multirow[t]{5}{*}{23} & HMS 41B & 5.80 & 46 & ICMB-843-22 & 5.84 \\
\hline & & & & Mean & 5.26 \\
\hline & C.D. $(p<0.05)$ & 0.37 & & C.D. $(p<0.05)$ & 0.37 \\
\hline & $\mathrm{SE}(\mathrm{d})$ & 0.18 & & $\mathrm{SE}(\mathrm{d})$ & 0.18 \\
\hline & C.V. $(\%)$ & 3.44 & & C.V. $(\%)$ & 3.44 \\
\hline
\end{tabular}

Table 4. Phytate content (mg/g) of selected pearl millet designated B-lines (CMS lines) grown during kharif-2013 and kharif-2014

\begin{tabular}{|c|c|c|c|c|}
\hline \multirow{2}{*}{ S. No. } & \multirow{2}{*}{ Pedigree } & \multicolumn{2}{|c|}{ Phytate } & \multirow[t]{2}{*}{ Mean } \\
\hline & & $\mathrm{K}-13$ & $\mathrm{~K}-14$ & \\
\hline 1 & HMS 13B & 1.31 & 6.87 & 4.09 \\
\hline 2 & HMS 39B & 3.85 & 5.53 & 4.69 \\
\hline 3 & HMS 36B & 3.89 & 5.92 & 4.91 \\
\hline 4 & HMS 33B & 4.07 & 5.97 & 5.02 \\
\hline 5 & HMS 40B & 4.29 & 6.38 & 5.34 \\
\hline 6 & HMS 21B & 4.45 & 6.19 & 5.32 \\
\hline
\end{tabular}




\begin{tabular}{clccc}
\hline 7 & HMS 7B & 4.73 & 6.31 & 5.52 \\
8 & HMS 52B & 4.80 & 6.31 & 5.56 \\
9 & HMS 38B & 5.19 & 5.89 & 5.54 \\
10 & HMS 32B & 5.67 & 6.63 & 6.15 \\
11 & ICMA89111 & 5.69 & 6.19 & 5.94 \\
12 & HMS 26B & 5.72 & 6.26 & 5.99 \\
13 & HMS 14B & 5.79 & 5.77 & 5.78 \\
14 & HMS 7B-1 & 5.82 & 6.22 & 6.02 \\
15 & HMS 16B & 5.86 & 7.16 & 6.51 \\
16 & HMS 53B & 5.90 & 5.96 & 5.93 \\
17 & HMS 18B & 5.98 & 6.99 & 6.49 \\
18 & HMS 59B & 5.99 & 5.92 & 5.96 \\
\hline & Mean & - & 6.25 & \\
& C.D. (p <0.05) & 0.37 & 0.15 & \\
\hline
\end{tabular}

Phytate content of screened pearl millet genotypes showed a significant variation from 1.31 to $6.8 \mathrm{mg} / \mathrm{g}$ during kharif-2013 and 4.95 to $7.16 \mathrm{mg} / \mathrm{g}$ during kharif-2014 (Tables 1 to 4). These values are corresponded with the earlier reports (Berwal et al. 2017a). Chauhan et al. (1986) and Reddy et al. (1986) reported a wide variation in phytic acid content of pearl millet varieties, valued between 0.18 to 1.67 $\%$, Kumar \& Chauhan (1993) also reported $825.7 \mathrm{mg} / 100 \mathrm{~g}$ phytic acid in pearl millet flour. Lestienne et al. (2005) reported in Gempela cultivar (yellow colour seeds) of pearl millet flour that phytate and iron binding phenolic compound contents were around 0.633 g/100 g. Reddy (2002) and Bravo (1998) also reported similar values for phytate content in pearl millet grains. Berwal at al. (2017b) reported that average phytate content of decorticated grain of eleven pearl millet hybrids/composites was $5.70 \mathrm{mg} / \mathrm{g}$, while in bran fraction it was $4.42 \mathrm{mg} / \mathrm{g}$. These data showed that phytate is distributed in pearl millet grain throughout the endosperm and bran fraction but the deposition is slightly dense in endosperm than that of bran fraction. Reddy (2002) and Bravo (1998) also reported the similar results. They reported that bran fraction of pearl millet had slightly lower phytate content $(4.09 \mathrm{mg} / \mathrm{g})$ than that of endosperm fraction $(6.32 \mathrm{mg} / \mathrm{g})$ because Phytate in pearl millet is mainly located in germ (Simwemba et al., 1984). Berwal et al. (2017c) also studied the phytate deposition in grain with flag leaf removal, but could not get significant change its deposition. In general, IP6 accumulates in the protein storage bodies as mixed salts called phytate that chelate a number of mineral cations. During the process of germination, endogenous grain phytase is activated, which degrades phytate, releasing stored phosphorus, myo-inositol and bound mineral cations (Raboy et al. 2000) that are further utilized by the developing seedlings. However, due to the lack of microbial phytase (Holm et al. 2002) monogastric animals (human beings, dogs, pigs, birds or agastric animals) are unable to remove the phosphates 
from the myo-inositol ring because they lack the intestinal digestive enzyme phytase, and are, therefore, incapable of utilizing the phosphorus present in food grains (Kuwano et al. 2006). About $70 \%$ of total $P$ in feed is released in excreta due to inefficient uptake of phosphorous by monogastric animals (Milko et al. 2008). Phytate works in a broad pHregion with six highly negative charged ions which make it a potent chelator therefore, its presence in the diet has a negative impact on the bioavailability of divalent and trivalent mineral ions such as $\mathrm{Fe}^{2+}, \mathrm{Zn}^{2+}, \mathrm{Ca}^{2+}, \mathrm{Mn}^{2+}$ and $\mathrm{Mg}^{2+}$ (Lopez et al. 2002; Fredlund et al. 2006). Since we could not find any pearl millet line with low phytate content among the screened germplasm lines, but some of the lines showed medium phytate content during both the season. Therefore, those lines with medium phytate content can be the good resource for generating low phytate containing line through crossing or shelfing.

\section{References}

Berwal, MK, Chugh LK, Goyal P, Kumar R \& Dev Vart. 2017a. Protein, Micronutrient, Antioxidant Potential and Phytate Content of Pearl Millet Hybrids and Composites Adopted for Cultivation by Farmers of Haryana, India. International Journal of Current Microbiology \& Applied Sciences, 6(3): 376-386.

Berwal MK, Verma K, Goyal P \& Chugh LK. 2017b. Impact of Decortication on Phytate Content in Pearl Millet Grains. Journal of Nutrition \& Food Science, 2: 006.

Berwal MK, Goyal P, Chugh LK \& Kumar R. 2017c. Impact of Flag Leaf Removal on Grain Development and Nutrients
Deposition in Pearl Millet Developing Grains. Vegetos, 31:1.

Berwal MK, Chugh LK, Goyal P \& Kumar R. 2016a. Variability in total phenolic content of pearl millet genotypes: inbreds and designated B-lines. Journal of Agriculture and Ecology, 1: 41-49.

Berwal MK, Chugh LK, Goyal P \& Kumar R. 2016b. Total Antioxidant Potential of Pearl Millet Genotypes: Inbreds and Designated B-lines. Indian Journal of Agricultural Biochemistry, 29 (2): 201204.

Bravo L. 1998. Polyphenols: Chemistry, dietary sources, metabolism, and nutritional significance. Nutrition Review, 56: 317-333.

Chauhan BM, Suneja N \& Bhat CM. 1986. Nutritive value and fatty acid composition of some high yielding varieties of Bajra. Bulletine on Grain Technology, 21: 441-442.

Fredlund K, Isaksson M, Rossander-Hulthen L, Almgren A \& Sandberg AS. 2006. Absorption of zinc and retention of calcium: Dose-dependent inhibition by phytate. Journal of Trace elements in Medicine and Biology, 20(1): 49-57.

Gupta N, Gupta AK, Gaur VS \& Kumar A. 2012. Relationship of nitrogen use efficiency with the activities of enzymes involved in nitrogen uptake and assimilation of finger millet genotypes grown under different nitrogen inputs. The Scientific World Journal, doi:10.1100/2012/625731.

Haug W \& Lentzsch HJ. 1983. Sensitive method for the rapid determination of Phytate in cereals and cereal products. Journal of the Science of Food and Agriculture, 34: 1423-1426. 
Holm PB, Kristiansen KN \& Pedersen HB. 2002. Transgenic approaches in commonly consumed cereals to improve iron and zinc content and bioavailability. The Journal of Nutrition, 132: 514-516.

Kumar A \& Chauhan BM. 1993. Effect of phytic acid on protein digestibility (in vitro) and $\mathrm{HCl}$-extractability of minerals in pearl millet sprouts. Cereal Chemistry, 70(5): 504-506.

Kuwano M, Ohyama A, Tanaka Y, Mimura T \& Takaiwa F. 2006. Molecular breeding for transgenic rice with low phytic acid phenotype through manipulating myoinositol 3 phosphate synthase gene. Molecular Breeding, 18(4): 263-272.

Lestienne I, Icard-Verniere C, Mouquet C, Picq C \& Treche S. 2005. Effects of soaking whole cereal and legume seeds on iron, zinc and phytate contents. Food Chemistry, 89: 421-425.

Lopez HW, Leenhardt F, Coudray C \& Remesy C. 2002. Minerals and phytic acid interactions: Is it a real problem for human nutrition. International Journal of Food Science \& Technology, 37: 727739.

Milko J, Oscar M, Fumito M, Petra M \& De La Maria LM. 2008. Current and future biotechnological applications of bacterial phytases and phytaseproducing bacteria. Microbes Environment, 23: 182-191.

Panse VG \& Sukhatme PV. 1957. Genetics and quantitative characters in relation to plant breeding. Indian Journal of Genetics, 17: 312-328.

Raboy V. 2001. Seeds for a better future: Low phytate grains help to overcome malnutrition and reduce pollution. Trends in Plant Science, 6: 458-462.
Raboy V, Gerbasi PF, Young KA, Stoneberg SD \& Pickett SG. 2000. Origin and seed phenotype of maize low phytic acid 1-1 and low phytic acid 2-1. Plant Physiology, 124: 355-368.

Reddy NR. 2002. Occurrence, distribution, content, and dietary intake of phytate. In Food phytates; N. R. Reddy and S. K. Sathe, Eds.; CRC Press: Boca Raton, FL; pp. 25-51.

Reddy VP, Faubion JM \& Hoseney RC. 1986. Odor generation in ground, stored pearl millet. Cereal Chemistry, 63(5): 403406.

Selle PH, Ravindarn V, Caldwell RA \& Bryden WL. 2000. Phytate and Phytase: Consequences for protein utilization. Nutrition Research Reviews, 13: 253278.

Shi J, Wang H, Schellin K, Li B, Faller M, Stoop JM, Meeley RB, Ertl DS, Ranch JP \& Glassman K. 2007. Embryospecific silencing of a transporter reduces phytic acid content of maize and soybeanseeds. Nature Biotechnology, 25: 930.

Shukla A \& Singh NK. 2012. Development and characterization of Indian Indam rice TILLING population and identification of mutants having low phytic acid content by endogenous phytase activity determination. Proceeding of world congress on Biotechnology, Hyderabad 4-6.

Simwemba CG, Hoseney RC, VarrianoMarston E \& Zeleznak K. 1984. Certain $\mathrm{B}$ vitamin and phytic acid contents of pearl millet [Pennisetum americanum (L.) Leeke]. Journal of Agricultural and Food Chemistry, 32: 31-37.

Taylor JRN. 2004. Millet: Pearl, In: Encyclopedia of grain science 2, ed. by Wrigley, C. Corke, H. and Walker, C.E., Elsevier, London, pp. 253-261. 